\title{
Effect of Sequential Inoculation with Non-Saccharomyces and Saccharomyces Yeasts on Riesling Wine Chemical Composition
}

\author{
Ophélie Dutraive ${ }^{1}$, Santiago Benito ${ }^{2, * \mathbb{C}}$, Stefanie Fritsch ${ }^{1}$, Beata Beisert ${ }^{1}$, Claus-Dieter Patz ${ }^{3}$ \\ and Doris Rauhut ${ }^{1}$ \\ 1 Bereich Getränkewissenschaften \& Lebensmittelsicherheit, Institut für Mikrobiologie und Biochemie, \\ Hochschule Geisenheim, Von-Lade-Straße 1, 65366 Geisenheim, Germany; \\ ophelie.dutraive@hotmail.fr (O.D.); Stefanie.Fritsch@hs-gm.de (S.F.); Beata.Beisert@hs-gm.de (B.B.); \\ Doris.Rauhut@hs-gm.de (D.R.) \\ 2 Departamento de Química y Tecnología de Alimentos, Universidad Politécnica de Madrid, Ciudad \\ Universitaria S/N, 28040 Madrid, Spain \\ 3 Bereich Getränkewissenschaften \& Lebensmittelsicherheit, Institut für Getränkeforschung, Hochschule \\ Geisenheim, Von-Lade-Straße 1, 65366 Geisenheim, Germany; Claus.Patz@hs-gm.de \\ * Correspondence: santiago.benito@upm.es; Tel.: +34-913363710 or +34-913363984
}

Received: 28 June 2019; Accepted: 29 August 2019; Published: 1 September 2019

\begin{abstract}
In recent years, studies have reported the positive influence of non-Saccharomyces yeast on wine quality. Many grape varieties under mixed or sequential inoculation show an overall positive effect on aroma enhancement. A potential impact by non-Saccharomyces yeast on volatile and non-volatile compounds should benefit the flavor of Riesling wines. Following this trend, four separate sequential fermentations (using the non-Saccharomyces yeasts Torulaspora delbrueckii, Metschnikowia pulcherrima, Pichia kluyveri, and Lachancea thermotolerans with Saccharomyces cerevisiae) were carried out on Riesling must and compared to a pure culture of $S$. cerevisiae. Sequential fermentations influenced the final wine aroma. Significant differences were found in esters, acetates, higher alcohols, fatty acids, and low volatile sulfur compounds between the different trials. Other parameters, including the production of non-volatile compounds, showed significant differences. This fermentation process not only allows the modulation of wine aroma but also chemical parameters such as glycerol, ethanol, alcohol, acidity, or fermentation by-products. These potential benefits of wine diversity should be beneficial to the wine industry.
\end{abstract}

Keywords: sequential inoculation; Saccharomyces; non-Saccharomyces; Riesling; aroma compound; Torulaspora delbrueckii; Pichia kluyveri; Lachancea thermotolerans

\section{Introduction}

Wine is considered to be one of the most complex aromatic products. It is composed of a large amount of aroma compounds and yet only a fraction of them are responsible for the bouquet. These compounds can be volatile, with these being the fragrant compounds, or non-volatile, with these being the compounds which are responsible for the taste sensations [1]. The final aromatic bouquet of the wine is the result of various factors: the raw material (variety, climate, vine management, and ripeness, etc.), the vinification choices, and the effect of microorganisms (yeast and lactic bacteria) [2]. In addition to the aromatic composition of the wine, it is important to note that each human has their own flavor perception. This perception is an interaction between three factors: the food properties, the in-mouth environment, and the psycho-social effects. As the aroma flavors lead to preferences for particular choices, the final bouquet of the wine plays a non-negligible role for the consumer taste [3]. 
Riesling is an aromatic grape variety which has been linked to various aroma compounds. Specific terpenes have been associated to this cultivar [1], such as monoterpenes, which are considered to be principally responsible for the floral and citrus character in wine [4]. The monoterpenes geraniol (rose and geranium notes) [5] and linalool (flower and lavender notes) [5] have been identified as typical for Riesling wines [6]. The thiols can also contribute to the bouquet of Riesling [7]. These compounds have a very low threshold, in the order of $1 \mathrm{ng} / \mathrm{L}$, and express grapefruit, passion fruit, box tree, or black current notes [8].

Two different kinds of aroma can be distinguished: the varietal aromas that are grape-variety-specific and the by-products of the alcoholic fermentation that are aromas produced by yeast metabolism.

Varietal aroma compounds are intrinsic to the grape variety. Currently, only a few varieties have been linked to certain aroma compounds such as the Muscat cultivars and its relatives, like Riesling, with specific terpenes [1]; Sauvignon Blanc [9], with thiols, or Cabernet Sauvignon, with methoxypyrazines [10]. However, only some free forms of aroma compounds, such as monoterpenes or methoxypyrazines, are present in the grape juice. Most of the aroma compounds occur in their linked form, which makes them non-volatile and hence odorless [2]. However, the linked aromas can be liberated through several processes by specific enzymes [11], yeast [12-14], or lactic bacteria [15]. Even if the differences of the aroma compound amount between varieties can seem small, it can have an enormous impact on the final product.

Three families of aromas are known as by-products of the alcoholic fermentations. The esters are a result of various pathways that appear during the alcoholic fermentation as a by-product of the fermentation by yeast [16]. Their proportion in wines is yeast-strain-specific and depends on the fermentation conditions (temperature and $\mathrm{pH}$ ), and evolves, positively or negatively, during wine aging [17]. The fatty acids can be separated into two groups: the straight chain fatty acids and the branched-chain fatty acids. They are both synthesized during the alcoholic fermentation through the yeast metabolism, but through different pathways [18]. The higher alcohols are synthesized by the yeast as an intermediate in amino acids metabolism. Thus, they are formed from various amino acids through two different pathways: the catabolic and the anabolic [18].

Since yeasts have an impact on the formation and the liberation of aroma compounds during alcoholic fermentation, yeast strains may play a role on the quantitative and qualitative production of these aromas. Nowadays, various strains are commercially available and promise aroma enhancement.

Only a few strains of non-Saccharomyces can complete alcoholic fermentation due to their sensitivity to high levels of ethanol. Moreover, they often produce undesirable secondary metabolites such as acetic acid, ethyl acetate, ethyl phenols, aldehydes, and acetoin $[19,20]$. Their oenological interest to the wine industry has been even less common given that they are $\mathrm{SO}_{2}$ sensitive and their fermentation rate is low $[21,22]$. However, since climate change is impacting the level of sugar in grapes, non-Saccharomyces have become quite popular for their ability to reduce the level of alcohol $[23,24]$. Renewed interest is being shown for their ability to enhance certain aromas and produce more complex wines $[12,25,26]$. As their pure fermentation is not oenologically interesting, they must be used along with a Saccharomyces spp. The sequential inoculation target is then to imitate the spontaneous fermentation by providing at the early stage non-Saccharomyces and at the middle stage Saccharomyces, while avoiding the disadvantages of indigenous yeast, namely the production of off-flavors as well as sluggish or stuck fermentation $[19,27,28]$.

Although some yeast strains can influence some specific volatile compounds to be over their sensory thresholds, wine is a complex matrix where individual compounds are occasionally difficult to perceive depending on the diversity of the matrix.

The aim of this work is to show the impact of non-Saccharomyces yeast on the wine's aroma modulation and to find the best strains to improve Riesling wine's flavor. To that purpose, four non-Saccharomyces yeasts were selected to be vinified under a sequential inoculation with a Saccharomyces cerevisiae. Their aroma profile was determined and compared to a wine fermented with only one S. cerevisiae strain. 


\section{Materials and Method}

\subsection{Yeast Strains}

Commercial strains from different companies were used for this trial: S. cerevisiae Level $2^{\circledR}$ (Lallemand, Montreal, QC, Canada), Torulaspora delbrueckii Level $2^{\circledR}$ (Lallemand, Montreal, Canada), Metschnikowia pulcherrima Flavia ${ }^{\circledR}$ (Lallemand, Montreal, Canada), Pichia kluyveri FrootZen ${ }^{\mathrm{TM}}$ (Hansen, Hørsholm, Denmark), and Lachancea thermotolerans Concerto ${ }^{\mathrm{TM}}$ (Hansen, Hørsholm, Denmark).

\subsection{Vinification}

Riesling grape juice from Hochschule Geisenheim University (Germany) was used to lead the microvinification after autoclaving $\left(115^{\circ} \mathrm{C}, 15 \mathrm{~min}, 20 \mathrm{psi}\right)$. Component concentration in the must were: sugar, $225.2 \mathrm{~g} / \mathrm{L}$; total dry extract, $237.8 \mathrm{~g} / \mathrm{L} ; \mathrm{pH}, 2.9$; total acidity, $8.7 \mathrm{~g} / \mathrm{L}$; tartaric acid, $4.7 \mathrm{~g} / \mathrm{L}$; acetic acid $<0.1 \mathrm{~g} / \mathrm{L}$; malic acid, $3.0 \mathrm{~g} / \mathrm{L}$; ethanol $<0.1 \mathrm{~g} / \mathrm{L}$; gluconic acid $<0.1 \mathrm{~g} / \mathrm{L}$; glycerol $<0.1 \mathrm{~g} / \mathrm{L}$; available primary amino acids $58.8 \mathrm{mg} / \mathrm{L} ;$ ammonium $48 \mathrm{mg} / \mathrm{L}$. In order to provide good conditions for the yeast to grow, the total nitrogen was adjusted to $250 \mathrm{mg} / \mathrm{L}$ with Vitamon ${ }^{\circledR}$ A (Erbslöh, Geisenheim, Germany) and nutrients were provided by Optimum White ${ }^{\mathrm{TM}}$ (Lallemand, Montreal, Canada), $30 \mathrm{~g} / \mathrm{hL}$. Bactiless $^{\mathrm{TM}}$ (Lallemand, Montreal, Canada), $30 \mathrm{~g} / \mathrm{hL}$, was added to avoid any bacterial contamination.

Five assays, in quadruplicate, were carried out in 2-liter bottles with $1.8 \mathrm{~L}$ of juice following a similar methodology to that described before but adapted to the scale [29]. A single inoculation with S. cerevisiae Level $2{ }^{\circledR}\left(10^{6} \mathrm{CFU} / \mathrm{mL}\right)$ was performed for the control trial (1) and sequential inoculation was performed for the other fermentations by inoculating first the juice with the non-Saccharomyces yeast strain $\left(10^{6} \mathrm{CFU} / \mathrm{mL}\right)$ and at $48 \mathrm{~h}\left(\right.$ T. delbrueckii Level $2^{\circledR}(2)$, M. pulcherrima Flavia ${ }^{\circledR}(3)$, and L. thermotolerans Concerto $^{\mathrm{TM}}(5)$ trials) or $96 \mathrm{~h}$ (P. kluyveri FrootZen ${ }^{\mathrm{TM}}$ (4) trial) after with the S. cerevisiae Level $2^{\circledR}$ $\left(10^{6} \mathrm{CFU} / \mathrm{mL}\right)$.

The inocula of the first inoculation were carried out in $100 \mathrm{~mL}$ of must and $1 \mathrm{~mL}$ of YEPD liquid media in a $250 \mathrm{~mL}$ Erlenmeyer flask. The YEPD liquid media was prepared with yeast extract $(10 \mathrm{~g} / \mathrm{L})$, peptone from casein $(20 \mathrm{~g} / \mathrm{L})$, and glucose $(20 \mathrm{~g} / \mathrm{L})$, and its $\mathrm{pH}$ was adjusted to 6.5. Yeast extract and glucose were provided by Merck (Darmstadt, Germany) and peptone by Roth ${ }^{\circledR}$ (Karlsruhe, Germany). The solution YEPD-must was autoclaved at $121{ }^{\circ} \mathrm{C}$ for $30 \mathrm{~min}$. It was inoculated with the dry yeast strains when the media was at ambient temperature under sterile conditions. Only the P. kluyveri FrootZen ${ }^{\mathrm{TM}}$ strain was previously rehydrated. This strain was a frozen product. The frozen solution was rehydrated in the must in a 250-mL Erlenmeyer flask and incubated at $26^{\circ} \mathrm{C}$ for $24 \mathrm{~h}$ before the inoculation of the YEPD liquid media. The inocula were cultivated in a chamber at $26^{\circ} \mathrm{C}$ for 7 days. Their final concentration was $10^{8} \mathrm{CFU} / \mathrm{mL}$. Forty-five milliliters of inocula per bottle were used to inoculate the juice. The bottles were sealed by fermenting bung in order to allow gas to be released and then stored at $20^{\circ} \mathrm{C}$. The inoculum for the second inoculation (S. cerevisiae Level ${ }^{\circledR}$ ) was performed according to recommendations of the yeast producer. Five grams of dry yeast were rehydrated in $50 \mathrm{~mL}$ of $35^{\circ} \mathrm{C}$ water for $20 \mathrm{~min}$. The inoculation $(3.6 \mathrm{~mL} / \mathrm{bottle})$ was carried out when the inoculum $\left(10^{9} \mathrm{CFU} / \mathrm{mL}\right)$ was about $20^{\circ} \mathrm{C}$. At the end of the fermentation monitored by weight loss, the bottles were stored in a $4{ }^{\circ} \mathrm{C}$ room to let the yeasts settle down. Then, the young wines were racked after $48 \mathrm{~h}$ and filled in brown glass bottles, according to the same procedure. Furthermore, potassium disulfite (Merck, Darmstadt, Germany) was added to each sample in a concentration of $80 \mathrm{mg} / \mathrm{L}$ sulfur dioxide before the bottles were locked with screw caps. Afterwards, the filled bottles were again stored at $4{ }^{\circ} \mathrm{C}$.

\subsection{Fermentation Kinetics}

Yeast strain kinetic growth was followed on two different agar media: a YEPD medium and a lysine medium [29]. The two media were chosen in order to differentiate Saccharomyces and non-Saccharomyces growth. The Saccharomyces yeast grows only on YEPD media whereas the non-Saccharomyces yeast grows on both. Aliquots were taken at regular intervals from the bottles of the quadruplicates of each 
assay. They were plated on both media in three different dilutions and incubated in a chamber at $26^{\circ} \mathrm{C}$ for $48 \mathrm{~h}$ before counting.

In order to estimate aliquot dilutions, their concentration in yeast $(\mathrm{CFU} / \mathrm{mL})$ was estimated by using a Thoma cell counting chamber (Marienfeld, Germany) under the microscope (objective $x 40$ ). The Thoma cell counting chamber was also used to estimate the inocula concentration. The weight of each bottle was taken regularly to follow the fermentation progress. The fermentation progress was calculated by the difference of the initial weight at day 0 and the weight from the day.

\subsection{Chemical Compounds Analysis}

\subsubsection{HPLC}

Organic acids measurements were performed by HPLC following the method described by Schneider et al. (1987) [30], which was adjusted and improved by Semmler et al. (2017) [31]. Measurements were carried out on the initial juice and obtained wines by the Department of Microbiology and Biochemistry at Hochschule Geisenheim University (HGU).

\subsubsection{FTIR}

Fourier transform middle infrared spectroscopy (FT-MIR) was used to assess density, alcohol, extract, sugars, $\mathrm{pH}$, glycerol, and $\mathrm{SO}_{2}$ measurements on initial juice and obtained wines. The method applied followed Baumgartner et al. (2001) [32], Patz et al. (1999) [33], and the Standard Operating Procedure SOP-WG1-84 of the HGU Department of Beverage Research.

\subsection{Volatile Compounds Analysis}

Volatile compound analysis was conducted by the HGU Department of Microbiology and Biochemistry. Fatty acids, higher alcohols, and esters were measured according to the method described by Rapp et al. (1994) [34] and modified by Fritsch et al. (2017a) [35]. A gas chromatography and mass spectrometer were performed to assess these volatile compounds. Terpenes were determined by the application of solid phase extraction (SPE), gas chromatography, and mass spectrometry following the method of Schüttler et al. (2015) [6], modified by Fritsch et al. (2017b) [36]. Headspace injection and the use of gas chromatography and pulsed flame photometric detection were achieved to measure low volatile compounds following the publication Rauhut et al. (2005) [37], adapted and modified by Rauhut, Beisert (2017) [38].

\subsection{Statistical Analysis}

R software (version 3.4.1, R Foundation for Statistical Computing, Vienna, Austria, 2017) and its package R-commander were used to perform all the statistical analyses. The significance level $p<0.05$ was chosen for all the applied tests.

\section{Results and Discussion}

\subsection{Fermentation Kinetics}

\subsubsection{Yeast Population Kinetics}

The yeast populations of the various fermentations processes are shown in Figure 1. Non-Saccharomyces yeasts started to decline between 2 to 4 days after the second inoculation with S. cerevisiae. Previous studies show similar trends on the decline of the non-Saccharomyces population shortly after inoculation with Saccharomyces spp. strain [39]. This phenomenon could have numerous explanations. It has previously been shown that yeast growth can be inhibited by yeast metabolites such as ethanol [40,41], medium chain fatty acids [42], and acetaldehyde [43]. Killer toxins produced during the exponential phase by specific strain can also have an inhibitory impact on some yeast 
growth [44-46]. More recently, it was found that S. cerevisiae could secrete peptides who inhibit non-Saccharomyces yeast growth [47]. Other parameters such as nutrient limitation and possible physical changes such as temperature and redox potential could also inhibit yeast developing.
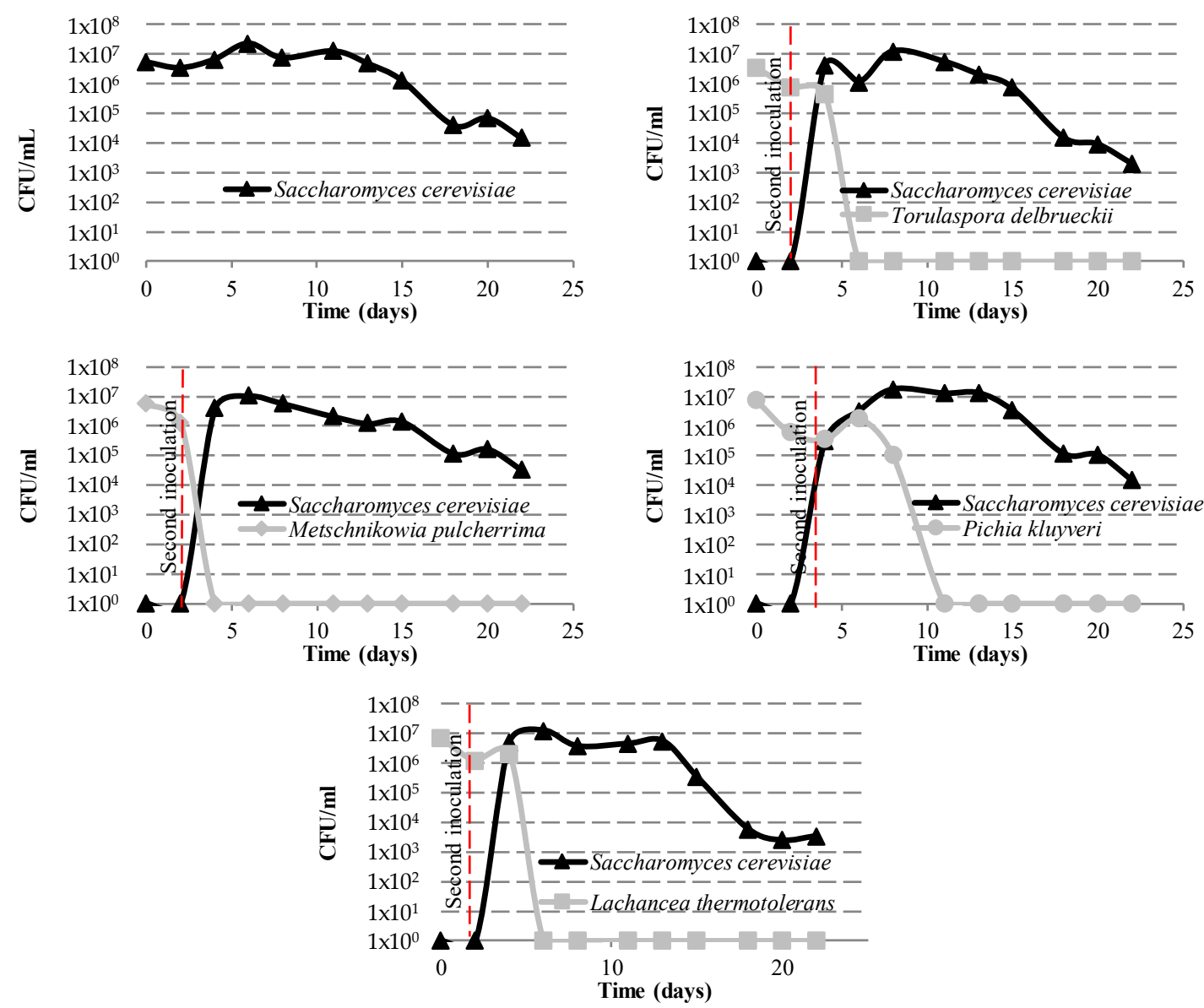

Figure 1. Population development of Saccharomyces cerevisiae, Torulaspora delbrueckii, Metschnikowia pulcherrima, Pichia kluyveri, and Lachancea thermotolerans during the fermentation process of the different trials.

\subsubsection{Alcoholic Fermentation Kinetics}

Figure 2 shows the alcoholic fermentation curves based on the weight losses of the replicates and trials during the fermentation process. For each assay, quadruplicates followed the same trend. The curves follow typical fermentation curves which have already been reported in the literature [48]. Fermentation dynamics show differences in the speed of sugar consumption. S. cerevisiae fermentation and M. pulcherrima sequential fermentation consumed sugars the fastest at the beginning of the alcoholic fermentation. However, other trails consumed the sugars faster during the following steps because all the fermentations reached the stationary phase at the same time. This difference of speed at the beginning could be attributed to the population density of $M$. pulcherrima, which declined immediately after the second inoculation, and the low fermentation rate and power of non-Saccharomyces species. As the other non-Saccharomyces populations declined later, their low fermentation power and rate, as has been reported by previous studies $[49,50]$, could be associated with a slower fermentation process [51]. 


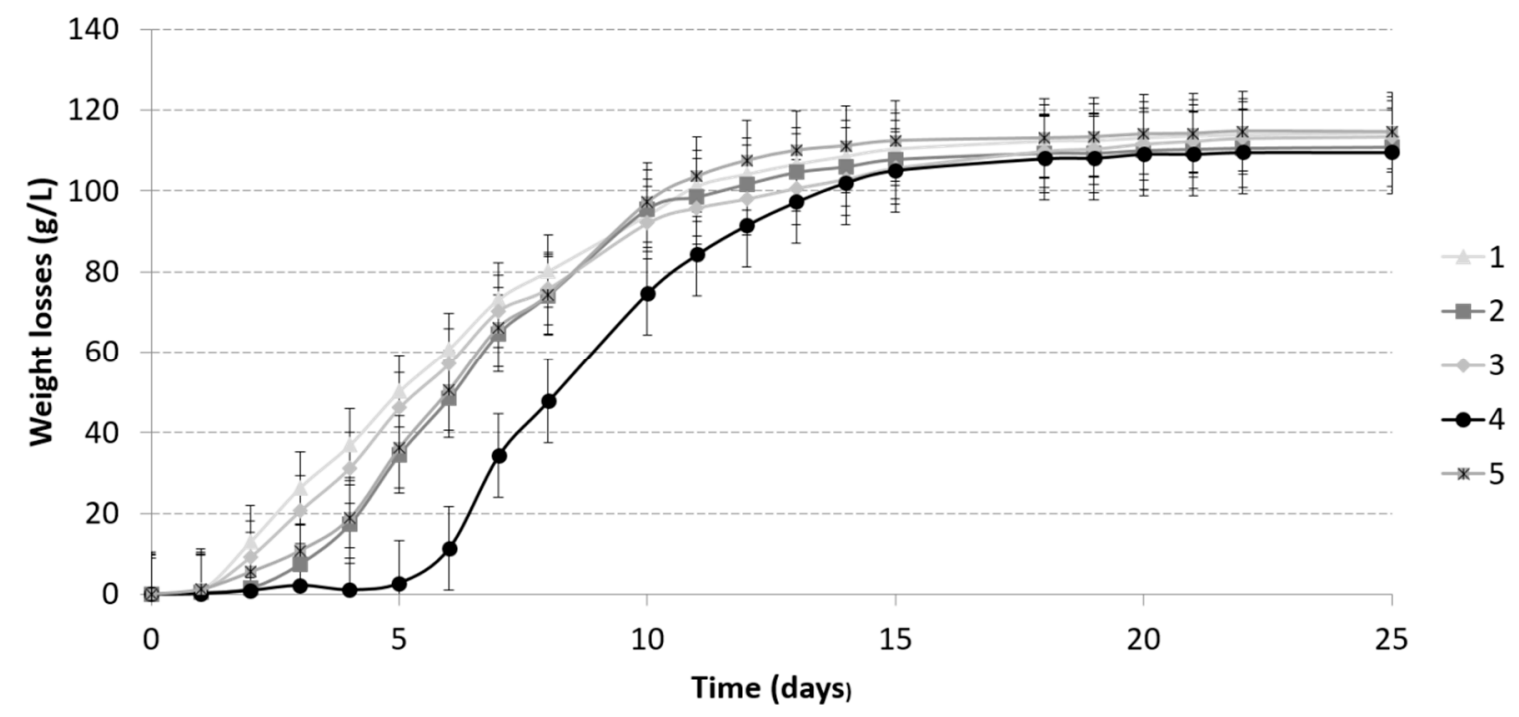

Figure 2. Alcoholic fermentation curve of S. cerevisiae Level $2^{\circledR}(1)$, and sequential fermentations with S. cerevisiae Level $2^{\circledR}$ and T. delbrueckii Level $2^{\circledR}(2)$, M. pulcherrima Flavia ${ }^{\circledR}(3)$, P. kluyveri FrootZen ${ }^{\mathrm{TM}}$ (4), and L. thermotolerans Concerto ${ }^{\mathrm{TM}}(5)$.

\subsection{Chemical Monitoring}

Tartaric acid was initially $5.2 \mathrm{~g} / \mathrm{L}$. Thus, all the fermentations show a decrease in tartaric acid in the wine between 0.48 and $0.77 \mathrm{~g} / \mathrm{L}$ (Table 1 ). This phenomenon can be explained by the precipitation of tartaric acid as calcium or potassium tartrate [52]. Tartaric acid can also be degraded by yeasts by up to $23 \%$ [53]. In this trial, the S. cerevisiae degraded the tartaric acid by the smallest amount and the sequential inoculation with T. delbrueckii, M. pulcherrima, and P. kluyveri by the greatest amount. It seems that the latter used more tartaric acid for their metabolisms.

Table 1. Final analysis, before adding $\mathrm{SO}_{2}$, of $S$. cerevisiae Level $2^{\circledR}(1)$, and sequential fermentations with S. cerevisiae Level $2{ }^{\circledR}$ and T. delbrueckii Level $2^{\circledR}(2)$, M. pulcherrima Flavia ${ }^{\circledR}(3)$, P. kluyveri FrootZen ${ }^{\mathrm{TM}}$ (4), and L. thermotolerans Concerto ${ }^{\mathrm{TM}}(5)$.

\begin{tabular}{cccccc}
\hline Compounds & $\mathbf{1}$ & $\mathbf{2}$ & $\mathbf{3}$ & $\mathbf{4}$ & $\mathbf{5}$ \\
\hline Tartaric acid $(\mathrm{g} / \mathrm{L})$ & $4.72 \pm 0.18 \mathrm{a}$ & $4.38 \pm 0.02 \mathrm{~b}$ & $4.43 \pm 0.01 \mathrm{~b}$ & $4.43 \pm 0.01 \mathrm{~b}$ & $4.63 \pm 0.28 \mathrm{ab}$ \\
Malic acid $(\mathrm{g} / \mathrm{L})$ & $2.28 \pm 0.00 \mathrm{~d}$ & $2.21 \pm 0.00 \mathrm{c}$ & $2.10 \pm 0.01 \mathrm{a}$ & $2.21 \pm 0.01 \mathrm{c}$ & $2.17 \pm 0.01 \mathrm{~b}$ \\
Shikimic acid $(\mathrm{mg} / \mathrm{L})$ & $50.19 \pm 0.06 \mathrm{~b}$ & $49.94 \pm 0.36 \mathrm{ab}$ & $49.36 \pm 0.25 \mathrm{a}$ & $49.86 \pm 0.34 \mathrm{ab}$ & $49.64 \pm 0.37 \mathrm{ab}$ \\
Lactic acid $(\mathrm{g} / \mathrm{L})$ & $0.21 \pm 0.01 \mathrm{a}$ & $0.17 \pm 0.01 \mathrm{a}$ & $0.21 \pm 0.01 \mathrm{a}$ & $0.19 \pm 0.00 \mathrm{a}$ & $1.51 \pm 0.04 \mathrm{~b}$ \\
Acetic acid $(\mathrm{g} / \mathrm{L})$ & $0.25 \pm 0.03 \mathrm{ab}$ & $0.21 \pm 0.03 \mathrm{a}$ & $0.30 \pm 0.03 \mathrm{~b}$ & $0.23 \pm 0.02 \mathrm{a}$ & $0.31 \pm 0.02 \mathrm{~b}$ \\
Citric acid $(\mathrm{g} / \mathrm{L})$ & $0.14 \pm 0.02 \mathrm{a}$ & $0.14 \pm 0.01 \mathrm{a}$ & $0.14 \pm 0.00 \mathrm{a}$ & $0.15 \pm 0.02 \mathrm{a}$ & $0.13 \pm 0.01 \mathrm{a}$ \\
Residual sugars $(\mathrm{g} / \mathrm{L})$ & $4.4 \pm 0.25 \mathrm{~b}$ & $2.8 \pm 0.23 \mathrm{a}$ & $4.5 \pm 0.30 \mathrm{~b}$ & $2.9 \pm 0.16 \mathrm{a}$ & $3.0 \pm 0.11 \mathrm{a}$ \\
pH & $3.1 \pm 0.00 \mathrm{a}$ & $3.2 \pm 0.00 \mathrm{~b}$ & $3.2 \pm 0.00 \mathrm{~b}$ & $3.2 \pm 0.00 \mathrm{~b}$ & $3.1 \pm 0.00 \mathrm{a}$ \\
Ethanol $(\%$ v/v) & $13.20 \pm 0.19 \mathrm{~b}$ & $13.17 \pm 0.44 \mathrm{~b}$ & $12.98 \pm 0.35 \mathrm{a}$ & $13.04 \pm 0.28 \mathrm{a}$ & $12.96 \pm 0.31 \mathrm{a}$ \\
Glycerol $(\mathrm{g} / \mathrm{L})$ & $5.8 \pm 0.04 \mathrm{a}$ & $6.6 \pm 0.04 \mathrm{~b}$ & $7.0 \pm 0.05 \mathrm{c}$ & $7.1 \pm 0.05 \mathrm{c}$ & $7.4 \pm 0.07 \mathrm{~d}$ \\
\hline
\end{tabular}

Average values of the quadruplicates \pm standard deviation. The letters represent significantly different statistical groups $(p<0.05)$.

Previous studies have shown that some yeasts are able to consume malic acid such as Issatchenkia orientalis, Saccharomyces spp., or Schizosaccharomyces spp. By up to $45 \%$ of the initial level [19,54-57]. The malic acid levels from 2.10 to $2.28 \mathrm{~g} / \mathrm{L}$ (Table 1) according to the assay are indeed lower than the initial malic acid level of the juice, which was $3.00 \mathrm{~g} / \mathrm{L}$. All the trials presented significant differences in their malic acid amount except for the sequential fermentation with $T$. delbrueckii and P. kluyveri, which can be seen to have had exactly the same production. The sequential fermentation with M. pulcherrima and the single fermentation with S. cerevisiae had the lowest and highest levels, 
respectively. Thus, M. pulcherrima shows a higher ability to consume malic acid than the other strains and S. cerevisiae shows a lower ability to consume malic acid.

Shikimic acid can be a precursor of aroma compounds such as ethyl cinnamate or benzaldehyde. Differences of the shikimic acid amount are shown. The level in the wines was found to be between 49.4 and $50.2 \mathrm{mg} / \mathrm{L}$ (Table 1). The fermentation with S. cerevisiae and the sequential fermentation with $M$. pulcherrima have the highest and the lowest amounts of shikimic acid, respectively. Thus, $M$. pulcherrima could have a positive impact on the formation of aroma compounds from this precursor.

Lactic acid concentrations were between 0.17 and $1.51 \mathrm{~g} / \mathrm{L}$, with the sequential fermentation with T. delbrueckii and L. thermotolerans having respectively the lowest and the highest levels (Table 1). Previous studies have reported high production of lactic acid by L. thermotolerans during its growth phase and its ability to acidify the must [28,58-62]. Assay 5, fermented with L. thermotolerans and $S$. cerevisiae, shows significantly higher production of lactic acid than the other trials, whereas the other trials do not show significant differences in their lactic acid production.

The acetic acid production (Table 1 ) varied from 0.21 to $0.31 \mathrm{~g} / \mathrm{L}$, according to the assay. No statistical differences are shown between the single fermentation with $S$. cerevisiae and the other trials, as has already been reported [49]. The sequential fermentations fermented with T. delbrueckii and P. kluyveri produced significantly lower acetic acid compared to the other non-Saccharomyces yeasts, which differs from previous studies. Nevertheless, the total amount of produced acetic acid does not negatively impact the wine quality [63].

The ethanol level ranges from 12.96 and $13.20 \%$ vol. (Table 1). Some strains are known for their ability to produce less alcohol $[64,65]$. Similar to what has been reported in the literature, the $S$. cerevisiae batch produced the highest ethanol level, albeit one that is not significantly different from that resulting from the sequential fermentation with T. delbrueckii [49]. The lowest level of ethanol was produced by the sequential inoculation with $L$. thermotolerans, though this level is not significantly different from the one produced by the sequential inoculations with M. pulcherrima and P. kluyveri. Similar results have already been found in the literature, showing that these yeasts can be used to produce low-alcohol wines [59,65]. In this trial, S. cerevisiae fermentation produced the highest level of ethanol, which confirms its high fermentative purity.

The level of $\mathrm{pH}$ was found to be not drastically different from one wine to another and ranged from 3.1 to 3.2 (Table 1). However, the statistical analysis shows significant differences. The fermentation with S. cerevisiae and the sequential fermentation with $L$. thermotolerans have lower $\mathrm{pH}$ levels, whereas the sequential fermentations with T. delbrueckii, M. pulcherrima and P. kluyveri have higher levels. Higher $\mathrm{pH}$ differences of $L$. thermotolerans with the other fermentations may be expected because of its high production of lactic acid $[28,66,67]$. Some studies confirm that even if lactic acid production is significantly higher for mixed fermentation with L. thermotolerans and S. cerevisiae than a single inoculation with the latter, the $\mathrm{pH}$ level can be significantly the same $[58,59]$.

Glycerol production varies from 5.8 to $7.4 \mathrm{~g} / \mathrm{L}$ for fermentation with $S$. cerevisiae and sequential fermentation with $L$. thermotolerans, having, respectively, the lowest and the highest production (Table 1). All of the other trials produced significantly higher levels of glycerol, which means that non-Saccharomyces have a positive impact on glycerol production. Higher production of this compound from sequential inoculation with non-Saccharomyces and Saccharomyces spp. has already been shown in the literature $[28,68-71]$.

\subsection{Volatile Compounds}

\subsubsection{Esters}

The total esters produced were between 124,842 and 194,053 $\mu \mathrm{g} / \mathrm{L}$ (Table 2). P. kluyveri sequential fermentation produced the highest level of esters and $L$. thermotolerans sequential fermentation produced an equally significant amount of esters. On the contrary, T. delbrueckii and M. pulcherrima sequential fermentations produced the lowest amount of esters. 
Table 2. Volatile compounds measured after alcoholic fermentations of S. cerevisiae Level $2^{\circledR}(1)$, and sequential fermentations with S. cerevisiae Level $2^{\circledR}$ and $T$. delbrueckii Level $2^{\circledR}(2)$, M. pulcherrima Flavia ${ }^{\circledR}$ (3), P. kluyveri FrootZen ${ }^{\mathrm{TM}}$ (4), and L. thermotolerans Concerto ${ }^{\mathrm{TM}}(5)$.

\begin{tabular}{|c|c|c|c|c|c|}
\hline Compounds & 1 & 2 & 3 & 4 & 5 \\
\hline \multicolumn{6}{|l|}{ Esters } \\
\hline \multicolumn{6}{|l|}{ Ethyl esters } \\
\hline Ethyl lactate $(\mathrm{mg} / \mathrm{L})$ & $\mathrm{nq}$ & $\mathrm{nq}$ & $\mathrm{nq}$ & $\mathrm{nq}$ & $52.26 \pm 3.27$ \\
\hline i-Ethyl butanoate $(\mu \mathrm{g} / \mathrm{L})$ & nd & nd & nd & nd & nd \\
\hline Ethyl butanoate $(\mu \mathrm{g} / \mathrm{L})$ & $432.19 \pm 31.18 b$ & $308.35 \pm 16.36 a$ & $332.37 \pm 20.24 a$ & $278.46 \pm 26.92 a$ & $304.86 \pm 15.42 \mathrm{a}$ \\
\hline Ethyl hexanoate $(\mu \mathrm{g} / \mathrm{L})$ & $1876.06 \pm 69.54 \mathrm{bc}$ & $1798.42 \pm 45.10 \mathrm{~b}$ & $1994.32 \pm 45.97 \mathrm{c}$ & $1551.1898 .47 a$ & $1518.12 \pm 28.25 \mathrm{a}$ \\
\hline Ethyl octanoate $(\mu \mathrm{g} / \mathrm{L})$ & $1472.32 \pm 89.10 \mathrm{ab}$ & $1367.63 \pm 33.80 \mathrm{a}$ & $1672.57 \pm 186.55 b$ & $1440.66 \pm 122.99 \mathrm{ab}$ & $1364.97 \pm 96.58 \mathrm{a}$ \\
\hline Ethyl decanoate $(\mu \mathrm{g} / \mathrm{L})$ & $442.63 \pm 57.49 \mathrm{a}$ & $437.23 \pm 37.76 a$ & $553.12 \pm 87.48 \mathrm{a}$ & $546.90 \pm 60.22 a$ & $581.35 \pm 47.92 \mathrm{a}$ \\
\hline Diethyl succinate $(\mu \mathrm{g} / \mathrm{L})$ & $\mathrm{nq}$ & $\mathrm{nq}$ & $\mathrm{nq}$ & $\mathrm{nq}$ & $\mathrm{nq}$ \\
\hline Ethyl 2-hydroxy-4-methyl valerate $(\mu \mathrm{g} / \mathrm{L})$ & $\mathrm{nq}$ & $\mathrm{nq}$ & $\mathrm{nq}$ & $\mathrm{nq}$ & $\mathrm{nq}$ \\
\hline Total ethyl esters $(\mu \mathrm{g} / \mathrm{L})$ & $4223.20 \pm 152.74 a$ & $3911.63 \pm 18.66 \mathrm{a}$ & $4552.38 \pm 305.74 a$ & $3817.20 \pm 282.13 a$ & $56031.95 \pm 3282.57 \mathrm{~b}$ \\
\hline \multicolumn{6}{|l|}{ Acetates } \\
\hline Ethyl acetate $(\mathrm{mg} / \mathrm{L})$ & $159.18 \pm 7.20 \mathrm{~b}$ & $135.02 \pm 9.10 \mathrm{a}$ & $115.53 \pm 6.80 \mathrm{a}$ & $184.01 \pm 5.02 \mathrm{c}$ & $127.97 \pm 10.25 \mathrm{a}$ \\
\hline $\begin{array}{l}\text { Isoamyl acetate and 2-methyl butyl acetate } \\
(\mu \mathrm{g} / \mathrm{L})\end{array}$ & $3927.41 \pm 186.64 \mathrm{a}$ & $4446.21 \pm 205.56 b c$ & $3779.80 \pm 90.54 a$ & $4751.71 \pm 257.79 \mathrm{c}$ & $4154.59 \pm 163.59 \mathrm{ab}$ \\
\hline Hexyl acetate $(\mu \mathrm{g} / \mathrm{L})$ & $694.15 \pm 29.53 b$ & $666.82 \pm 11.07 \mathrm{~b}$ & $626.61 \pm 38.94 \mathrm{ab}$ & $590.44 \pm 34.53 a$ & $592.86 \pm 23.73 a$ \\
\hline Ethyl phenylacetate $(\mu \mathrm{g} / \mathrm{L})$ & $\mathrm{nq}$ & $\mathrm{nq}$ & $\mathrm{nq}$ & $\mathrm{nq}$ & $\mathrm{nq}$ \\
\hline 2-Phenyl-ethyl acetate $(\mu \mathrm{g} / \mathrm{L})$ & $429.43 \pm 9.15 b$ & $510.21 \pm 16.05 c$ & $352.56 \pm 14.12 \mathrm{a}$ & $885.06 \pm 28.39 \mathrm{~d}$ & $375.91 \pm 8.12 \mathrm{a}$ \\
\hline Total acetates $(\mu \mathrm{g} / \mathrm{L})$ & $164229.49 \pm 7358.44 c$ & $140647.20 \pm 9289.39 \mathrm{~b}$ & $120290.10 \pm 6811.04 \mathrm{a}$ & $190236.09 \pm 5279.61 \mathrm{~d}$ & $133095.47 \pm 10391.01 \mathrm{ab}$ \\
\hline Total esters $(\mu \mathrm{g} / \mathrm{L})$ & $168452.69 \pm 7369.92 b$ & $144558.83 \pm 9282.59 \mathrm{a}$ & $124842.48 \pm 6791.85 \mathrm{a}$ & $194053.29 \pm 5518.21 \mathrm{c}$ & $189127.42 \pm 9985.27 \mathrm{c}$ \\
\hline \multicolumn{6}{|l|}{ Higher alcohols } \\
\hline $\begin{array}{l}\text { 3-Methyl-butanol and 2-methyl-butanol } \\
(\mathrm{mg} / \mathrm{L})\end{array}$ & $188.62 \pm 9.08 \mathrm{a}$ & $230.96 \pm 8.93 \mathrm{~b}$ & $212.96 \pm 11.85 \mathrm{ab}$ & $224.83 \pm 15.01 \mathrm{~b}$ & $212.78 \pm 10.67 \mathrm{ab}$ \\
\hline 2-Phenyl-ethanol (mg/L) & $13.74 \pm 1.20 \mathrm{a}$ & $23.42 \pm 0.95 c$ & $18.00 \pm 0.60 \mathrm{~b}$ & $28.62 \pm 1.39 \mathrm{~d}$ & $23.38 \pm 1.00 \mathrm{c}$ \\
\hline Hexanol $(\mu \mathrm{g} / \mathrm{L})$ & $1131.24 \pm 37.40 \mathrm{~b}$ & $1208.40 \pm 53.76 \mathrm{bc}$ & $1277.45 \pm 71.62 c$ & $677.55 \pm 15.71 \mathrm{a}$ & $1415.87 \pm 43.94 \mathrm{~d}$ \\
\hline Total higher alcohols $(\mathrm{mg} / \mathrm{L})$ & $203.48 \pm 9.95 a$ & $255.59 \pm 9.61 \mathrm{~b}$ & $232.23 \pm 11.84 \mathrm{ab}$ & $254.14 \pm 15.91 \mathrm{~b}$ & $237.58 \pm 11.63 b$ \\
\hline \multicolumn{6}{|l|}{ Fatty acids } \\
\hline Hexanoic acid (mg/L) & $11.13 \pm 0.30 \mathrm{~cd}$ & $10.78 \pm 0.17 \mathrm{bc}$ & $11.38 \pm 0.14 \mathrm{~d}$ & $10.41 \pm 0.15 \mathrm{ab}$ & $9.90 \pm 0.21 \mathrm{ab}$ \\
\hline Octanoic acid $(\mathrm{mg} / \mathrm{L})$ & $11.99 \pm 0.20 \mathrm{c}$ & $10.96 \pm 0.25 \mathrm{bc}$ & $11.56 \pm 0.75 c$ & $10.31 \pm 0.35 b$ & $9.05 \pm 0.41 \mathrm{a}$ \\
\hline Decanoic acid $(\mu \mathrm{g} / \mathrm{L})$ & $4209.93 \pm 141.19 c$ & $3975.70 \pm 119.78 b c$ & $4233.22 \pm 178.75 c$ & $3434.45 \pm 229.12 \mathrm{a}$ & $3718.80 \pm 67.31 \mathrm{ab}$ \\
\hline i-Valeric acid $(\mu \mathrm{g} / \mathrm{L})$ & $1446.64 \pm 12.53 a$ & $1493.16 \pm 21.54 a$ & $1458.47 \pm 20.22 \mathrm{a}$ & $2093.35 \pm 19.51 b$ & $1491.55 \pm 19.36 \mathrm{a}$ \\
\hline Total fatty acids (mg/L) & $28.79 \pm 0.38 c$ & $27.21 \pm 0.39 b c$ & $28.64 \pm 1.03 c$ & $26.26 \pm 0.67 \mathrm{~b}$ & $24.15 \pm 0.51 a$ \\
\hline
\end{tabular}


Table 2. Cont.

\begin{tabular}{|c|c|c|c|c|c|}
\hline Compounds & 1 & 2 & 3 & 4 & 5 \\
\hline \multicolumn{6}{|l|}{ Terpenes } \\
\hline Linalool oxide $1(\mu \mathrm{g} / \mathrm{L})$ & $\mathrm{nq}$ & $\mathrm{nq}$ & $\mathrm{nq}$ & $\mathrm{nq}$ & $\mathrm{nq}$ \\
\hline Linalool oxide $2(\mu \mathrm{g} / \mathrm{L})$ & nq & nq & $\mathrm{nq}$ & $\mathrm{nq}$ & $\mathrm{nq}$ \\
\hline Linalool $(\mu \mathrm{g} / \mathrm{L})$ & $54.52 \pm 1.96 a$ & $56.06 \pm 1.16 \mathrm{a}$ & $56.97 \pm 1.49 a$ & $56.61 \pm 2.17 a$ & $57.85 \pm 2.54 a$ \\
\hline$\alpha$-Terpineol $(\mu \mathrm{g} / \mathrm{L})$ & $37.27 \pm 0.64 a$ & $37.46 \pm 0.89 a$ & $36.92 \pm 0.61 \mathrm{a}$ & $38.51 \pm 0.90 \mathrm{a}$ & $37.81 \pm 0.60 \mathrm{a}$ \\
\hline Total terpenes $(\mu \mathrm{g} / \mathrm{L})$ & $91.80 \pm 2.15 a$ & $93.52 \pm 1.05 a$ & $93.89 \pm 2.01 \mathrm{a}$ & $95.12 \pm 2.65 a$ & $95.65 \pm 2.91 \mathrm{a}$ \\
\hline \multicolumn{6}{|c|}{ Low volatile sulfur compounds } \\
\hline $\mathrm{H}_{2} \mathrm{~S}$ & $3.48 \pm 028 a$ & $5.85 \pm 0.15 b$ & $6.28 \pm 0.29 b c$ & $7.65 \pm 0.87 \mathrm{~cd}$ & $7.78 \pm 0.82 \mathrm{~d}$ \\
\hline $\mathrm{MeSH}$ & $\mathrm{nq}$ & $\mathrm{nq}$ & $\mathrm{nq}$ & $\mathrm{nq}$ & nq \\
\hline
\end{tabular}

Average values of the quadruplicates \pm standard deviation. The letters represent significantly different statistical groups $(p<0.05)$. Legend: nd, not detected; nq, not quantifiable (traces). 
While previous studies are in accordance with this M. pulcherrima sequential fermentations result regarding the concentration of esters, others have found higher production of ester compounds than Saccharomyces spp. single fermentation $[29,72]$. Nevertheless, M. pulcherrima sequential fermentation produced the highest level of ethyl hexanoate and ethyl octanoate. These compounds confer apple peel and fruit flavors to the wine. Similar results have already been reported [14,73]. In previous studies, ethyl acetate production was reported higher for M. pulcherrima than the S. cerevisiae control [72,74]. In the present study, Metschnikowia pulcherrima produced the lowest amount of ethyl acetate (Table 2), as has been demonstrated by other authors [29].

T. delbrueckii produced higher levels of acetate compounds than the S. cerevisiae fermentation, producing higher concentrations of compounds such as isoamyl acetate, 2-methyl butyl acetate, and 2-phenyl-ethyl acetate. Other authors have reported a higher production of 2-phenyl-ethyl acetate $[13,27,75]$.

Previous studies have highlighted the ability of P. kluyveri to produce ester compounds [76,77]. Total esters were produced the most by this strain. While its production of acetate esters was significantly higher than the $S$. cerevisiae control, its ethyl esters production did not differ. This result is not in agreement with the literature [29]. This difference could be explained by the length of time between the first and the second inoculation. If this is the case, a longer fermentation with P. kluyveri should improve the production of acetate ester. The different results can also be explained by the interaction between yeasts that can influence wine aroma $[64,78]$. The P. kluyveri trial also produced higher levels of isoamyl acetate, 2-methyl butyl acetate, and 2-phenyl-ethyl acetate than the other variants.

L. thermotolerans produced the highest level of ethyl esters. This high level is mainly related to the production of ethyl lactate. The trial produced the lowest amount of all the ethyl esters measured but it was the only producer of ethyl lactate (Table 2). However, the final concentration of ethyl lactate was lower than the sensory threshold of $60 \mathrm{mg} / \mathrm{L}[28,79]$. Some studies have previously reported higher production of ethyl lactate by L. thermotolerans sequential fermentation than by Saccharomyces spp. single fermentation [59]. Ethyl lactate production might be favored by the formation of lactic acid which can produce ethyl lactate by an esterification reaction with ethanol [80]. Total esters were higher than the $S$. cerevisiae control. The total amount of esters is also influenced by the production of ethyl lactate. All the measured acetates were lower or equal to the $S$. cerevisiae control (Table 2). Thus, L. thermotolerans enhanced the milky and fruity flavors associated with ethyl lactate $[28,79]$.

\subsubsection{Higher Alcohols}

Four higher alcohols were analyzed for the wines and shown in Table 2. Three of them were detected at levels above their odor threshold [5], with the exception of hexanol. T. delbrueckii sequential fermentation produced the highest level of higher alcohols, $256 \mathrm{mg} / \mathrm{L}$ (Table 2), but this trial was not significantly different to the other sequentially fermented assays.

P. kluyveri produced significantly more alcohols than the S. cerevisiae control. It produced significantly the highest level of 2-phenylethanol than the other trials, giving pleasant flavors such as honey, spice, rose, and lilac [5]. It also produced a significantly higher level of 3-methyl-butanol and 2-methylbutanol, which confer whiskey, malt, and burnt notes.

L. thermotolerans produced higher levels of higher alcohols in total than the S. cerevisiae control. In particular, it produced more of the 2-phenyl-ethanol, honey, spice, rose, and lilac fragrances than the S. cerevisiae control, and the greatest amount of the hexanol compound, resin, flower, and green fragrances [5]. While levels of both compounds are under their perception threshold, the level of higher alcohol contributes positively to the wine aroma [5].

\subsubsection{Fatty Acids}

Fatty acids were detectable via the analysis (Table 2). Four of them were analyzed and found in higher quantities relative to their odor threshold [5]. The total amount of fatty acid production ranged from 24 to $29 \mathrm{mg} / \mathrm{L}$ (Table 2). S. cerevisiae fermentation produced the highest levels of fatty 
acids, followed by the sequential fermentation with M. pulcherrima. Both trials' levels were significantly equal according to the statistic. On the contrary, L. thermotolerans sequential fermentation produced the lowest levels.

P. kluyveri produced less fatty acids than the control. However, it produced significantly higher levels of i-valeric acid than other fermentations. This compound confers unpleasant notes such as sweat, acid, and a rancid flavor [5].

\subsubsection{Terpenes}

Four terpene compounds were analyzed but only two of them were quantifiable. Moreover, no significant differences were found between them. Levels of linalool, known for its flower and lavender notes [5], ranged between 55 and $58 \mu \mathrm{g} / \mathrm{L}$ (Table 2). This compound was produced in higher quantities than its perception threshold, $25.2 \mu \mathrm{g} / \mathrm{L}$ [5], and therefore contributed to the bouquet of the wine.

\subsubsection{Low Volatile Sulfur Compounds}

Among the analyzed low volatile sulfur compounds, only $\mathrm{H}_{2} \mathrm{~S}$ was detectable and quantifiable. Levels ranged from 3 to $8 \mu \mathrm{g} / \mathrm{L}$ (Table 2). According to the literature, the $\mathrm{H}_{2} \mathrm{~S}$ threshold varies across a wide range and a negative contribution to the flavor can already be expected at low microgram concentrations [81]. Thus, it could be sensorially detectable. S. cerevisiae fermentation produced a significantly lower amount of $\mathrm{H}_{2} \mathrm{~S}$ than sequential fermentations with non-Saccharomyces. On the contrary, L. thermotolerans produced the highest amount of $\mathrm{H}_{2} \mathrm{~S}$. The high variability between strains and yeasts $[49,82-84]$ and the limited information on $\mathrm{H}_{2} \mathrm{~S}$ production from sequential inoculation fermentation do not allow the confirmation of those results.

\section{Conclusions}

In this work, the ability of various yeast strains to enhance the aroma of Riesling wines was investigated. Five commercial wine yeast strains were chosen in order to compare their impact on the wine chemical composition. Four non-Saccharomyces species strains were selected due to their ability to produce specific aromas compared to a classic fermentation with a S. cerevisiae. Sequential inoculation allowed the modulation of the wines' non-volatile compound production. Significant differences between the trials of chemical parameters such as ethanol, $\mathrm{pH}$, and glycerol were found in this study. Differences in volatile compounds were observed for esters, higher alcohols, fatty acids, and low volatile sulfur compounds. T. delbrueckii sequential fermentation produced the lowest acetic acid concentration and the highest concentration of higher alcohols. M. pulcherrima sequential fermentation produced the highest levels of ethyl hexanoate, ethyl octanoate, and shikimic acid. The P. kluyveri trial produced the highest concentrations of total esters, glycerol, and i-valeric acid. L. thermotolerans produced the highest concentrations of lactic acid, ethyl lactate, and $\mathrm{H}_{2} \mathrm{~S}$.

Author Contributions: D.R., S.B. and O.D. developed the experimental design; O.D. performed the vinifications; O.D. and S.B. performed the formal data analysis and supervised the project; O.D., S.B. and D.R. wrote the article; D.R., S.F. and B.B. performed gas chromatographic analysis; C.-D.P. introduced to the FTIR analysis and assisted to data acquisition and statistical analysis. All authors discussed the results and contributed to the final manuscript.

Funding: This project has been co-funded by the Erasmus+ program of the European Union, through Vinifera Euromaster (www.vinifera-euromaster.eu). Funding for Santiago Benito was provided by Ossian Vides y Vinos S. L under the framework of the project FPA1720300120 (Centre for the Development of Industrial Technology (CDTI), Spain).

Acknowledgments: Anja Giehl (Department of Beverage Research, HGU) is gratefully acknowledged for her assistance in FTIR-measuring, Carmen Dost for her help to control the fermentation trial, and Heike Semmler for her support in the HPLC analysis (Department of Microbiology and Biochemistry, HGU).

Conflicts of Interest: The authors declare no conflict of interest. 


\section{References}

1. Rapp, A.; Mandery, H. ChemInform Abstract: Wine Aroma. Chem. Informationsd. 1986, 42, 873. [CrossRef]

2. Fischer, U. Wine aroma. In Flavours and Fragrances: Chemistry, Bioprocessing and Sustainability; Springer: Berlin/Heidelberg, Germany, 2007; ISBN 9783540493389.

3. German, J.B.; Yeritzian, C.; Tolstoguzov, V.B. Olfaction, where nutrition, memory and immunity intersect. In Flavours and Fragrances: Chemistry, Bioprocessing and Sustainability; Springer: Berlin/Heidelberg, Germany, 2007; ISBN 9783540493389.

4. Martin, D.M.; Chiang, A.; Lund, S.T.; Bohlmann, J. Biosynthesis of wine aroma: Transcript profiles of hydroxymethylbutenyl diphosphate reductase, geranyl diphosphate synthase, and linalool/nerolidol synthase parallel monoterpenol glycoside accumulation in Gewürztraminer grapes. Planta 2012, 236, 919-929. [CrossRef] [PubMed]

5. Francis, I.L.; Newton, J.L. Determining wine aroma from compositional data. Aust. J. Grape Wine Res. 2005, 11, 114-126. [CrossRef]

6. Schüttler, A.; Friedel, M.; Jung, R.; Rauhut, D.; Darriet, P. Characterizing aromatic typicality of riesling wines: Merging volatile compositional and sensory aspects. Food Res. Int. 2015, 69, 26-37. [CrossRef]

7. Tominaga, T.; Masneuf, I.; Dubourdieu, D. Powerful Aromatic Volatile Thiols in Wines Made from Several Vitis vinifera Grape Varieties and Their Releasing Mechanism. In Nutraceutical Beverages: Chemistry, Nutrition, and Health Effects; American Chemical Society: Washington, DC, USA, 2009.

8. Peña-Gallego, A.; Hernández-Orte, P.; Cacho, J.; Ferreira, V. S-Cysteinylated and S-glutathionylated thiol precursors in grapes. A review. Food Chem. 2012, 131, 1-13. [CrossRef]

9. Tominaga, T.; Murat, M.-L.; Dubourdieu, D. Development of a Method for Analyzing the Volatile Thiols Involved in the Characteristic Aroma of Wines Made from Vitis vinifera L. Cv. Sauvignon Blanc. J. Agric. Food Chem. 1998, 46, 1044-1048. [CrossRef]

10. Roujou de Boubee, D.; Van Leeuwen, C.; Dubourdieu, D. Organoleptic impact of 2-methoxy-3-isobutylpyrazine on red Bordeaux and Loire wines. Effect of environmental conditions on concentrations in grapes during ripening. J. Agric. Food Chem. 2000, 48, 4830-4834. [CrossRef] [PubMed]

11. Rusjan, D.; Strlič, M.; Košmerl, T.; Prosen, H. The response of monoterpenes to different enzyme preparations in Gewürztraminer (Vitis vinifera L.) wines. S. Afr. J. Enol. Vitic. 2009, 30, 56-64. [CrossRef]

12. Gamero, A.; Quintilla, R.; Groenewald, M.; Alkema, W.; Boekhout, T.; Hazelwood, L. High-throughput screening of a large collection of non-conventional yeasts reveals their potential for aroma formation in food fermentation. Food Microbiol. 2016, 60, 147-159. [CrossRef] [PubMed]

13. Belda, I.; Ruiz, J.; Beisert, B.; Navascués, E.; Marquina, D.; Calderón, F.; Rauhut, D.; Benito, S.; Santos, A. Influence of Torulaspora delbrueckii in varietal thiol (3-SH and 4-MSP) release in wine sequential fermentations. Int. J. Food Microbiol. 2017, 257, 183-191. [CrossRef]

14. Ruiz, J.; Belda, I.; Beisert, B.; Navascués, E.; Marquina, D.; Calderón, F.; Rauhut, D.; Santos, A.; Benito, S. Analytical impact of Metschnikowia pulcherrima in the volatile profile of Verdejo white wines. Appl. Microbiol. Biotechnol. 2018, 102, 8501-8509. [CrossRef] [PubMed]

15. Grimaldi, A.; Bartowsky, E.; Jiranek, V. Screening of Lactobacillus spp. and Pediococcus spp. for glycosidase activities that are important in oenology. J. Appl. Microbiol. 2005, 95, 1061-1069. [CrossRef] [PubMed]

16. Saerens, S.M.G.; Verstrepen, K.J.; Van Laere, S.D.M.; Voet, A.R.D.; Van Dijck, P.; Delvaux, F.R.; Thevelein, J.M. The Saccharomyces cerevisiae EHT1 and EEB1 genes encode novel enzymes with medium-chain fatty acid ethyl ester synthesis and hydrolysis capacity. J. Biol. Chem. 2006, 281, 4446-4456. [CrossRef] [PubMed]

17. Molina, A.M.; Swiegers, J.H.; Varela, C.; Pretorius, I.S.; Agosin, E. Influence of wine fermentation temperature on the synthesis of yeast-derived volatile aroma compounds. Appl. Microbiol. Biotechnol. 2007, 77, 675-687. [CrossRef] [PubMed]

18. Ugliano, M.; Henschke, P.A. Yeasts and wine flavour. In Wine Chemistry and Biochemistry; Springer: New York, NY, USA, 2009; ISBN 9780387741161.

19. Benito, S. The impacts of Schizosaccharomyces on winemaking. Appl. Microbiol. Biotechnol. 2019, 103, 4291-4312. [CrossRef] [PubMed]

20. Benito, S.; Palomero, F.; Morata, A.; Calderón, F.; Suárez-Lepe, J.A. A method for estimating Dekkera/Brettanomyces populations in wines. J. Appl. Microbiol. 2009, 106, 1743-1751. [CrossRef] [PubMed] 
21. Mendoza, L.; Farías, M.E. Improvement of wine organoleptic characteristics by non-Saccharomyces yeasts. Appl. Microbiol. 2010, 2, 908-919.

22. Ciani, M.; Comitini, F.; Mannazzu, I.; Domizio, P. Controlled mixed culture fermentation: A new perspective on the use of non-Saccharomyces yeasts in winemaking. FEMS Yeast Res. 2010, 10, 123-133. [CrossRef]

23. Contreras, A.; Curtin, C.; Varela, C. Yeast population dynamics reveal a potential 'collaboration' between Metschnikowia pulcherrima and Saccharomyces uvarum for the production of reduced alcohol wines during Shiraz fermentation. Appl. Microbiol. Biotechnol. 2015, 99, 1885-1895. [CrossRef]

24. Maturano, Y.P.; Mestre, M.V.; Kuchen, B.; Toro, M.E.; Mercado, L.A.; Vazquez, F.; Combina, M. Optimization of fermentation-relevant factors: A strategy to reduce ethanol in red wine by sequential culture of native yeasts. Int. J. Food Microbiol. 2019, 289, 40-48. [CrossRef]

25. Andorra, I.; Monteiro, M.; Esteve-Zarzoso, B.; Albergaria, H.; Mas, A. Analysis and direct quantification of Saccharomyces cerevisiae and Hanseniaspora guilliermondii populations during alcoholic fermentation by fluorescence in situ hybridization, flow cytometry and quantitative PCR. Food Microbiol. 2011, 28, 1483-1491. [CrossRef] [PubMed]

26. Morales, M.L.; Fierro-Risco, J.; Ríos-Reina, R.; Ubeda, C.; Paneque, P. Influence of Saccharomyces cerevisiae and Lachancea thermotolerans co-inoculation on volatile profile in fermentations of a must with a high sugar content. Food Chem. 2019, 276, 427-435. [CrossRef] [PubMed]

27. Benito, S. The impact of Torulaspora delbrueckii yeast in winemaking. Appl. Microbiol. Biotechnol. 2018, 102, 3081-3094. [CrossRef] [PubMed]

28. Benito, S. The impacts of Lachancea thermotolerans yeast strains on winemaking. Appl. Microbiol. Biotechnol. 2018, 102, 6775-6790. [CrossRef] [PubMed]

29. Benito, S.; Hofmann, T.; Laier, M.; Lochbühler, B.; Schüttler, A.; Ebert, K.; Fritsch, S.; Röcker, J.; Rauhut, D. Effect on quality and composition of Riesling wines fermented by sequential inoculation with non-Saccharomyces and Saccharomyces cerevisiae. Eur. Food Res. Technol. 2015, 241, 707-717. [CrossRef]

30. Schneider, A.; Gerbi, V.; Redoglia, M. A Rapid HPLC Method for Separation and Determination of Major Organic Acids in Grape Musts and Wines. Am. J. Enol. Vitic. 1987, 38, 151-155.

31. Semmler, H.; Sponholz, W.-R.; Rauhut, D. Standard Operating Procedure (SOP) for the Analysis of Organic Acids in Wines by HPLC; Hochschule Geisenheim University: Geisenheim, Germany, 2017.

32. Baumgartner, D.; Bill, R.; Roth, I. Traubenmostanalyse mit Hilfe der. FTIR-Spektroskopie. Schweizerische Zeitschrift Obs. Weinbau 2001, 2, 46-48.

33. Patz, C.D.; David, A.; Thente, K.; Kuerbel, P.; Dietrich, H. Wine analysis with FTIR spectrometry. Wein-Wiss. Vitic. Enol. Sci. 1999, 54, 80-87.

34. Rapp, A.; Yavas, I.; Hastrich, H. Einfache und schnelle Anreicherung ("Kaltronmethode") von Aromastoffen des Weines und deren quantitative Bestimmung mittels Kapillargaschromatographie. Dtsch. Leb. 1994, 90, 171-174.

35. Fritsch, S.; Brezina, S.; Ebert, K.; Rauhut, D. Standard Operating Procedure (SOP) for the Analysis of the Fermentation Bouquet in Wines; Department of Microbiology Biochemistry Hochschule Geisenheim University: Geisenheim, Germany, 2017.

36. Fritsch, S.; Ebert, K.; Brand, M.; Rauhut, D. Standard Operating Procedure (SOP) for the Analysis of Terpens and Norisoprenoids in Wines; Department of Microbiology Biochemistry Hochschule Geisenheim University: Geisenheim, Germany, 2017.

37. Rauhut, D.; Beisert, B.; Berres, M.; Gawron-Scibek, M.; Kürbel, H. Pulse flame photometric detection: An innovative technique to analyse volatile sulfur compounds in wine and other beverages. In State-of-the-Art in Flavour Chemistry and Biology; Hofmann, T., Rothe, M., Schieberle, P., Eds.; Deutsche Forschungsanstalt für Lebensmittelchemie: Garching, Germany, 2005; pp. 363-367. ISBN 3-00-015809-X.

38. Rauhut, D.; Beisert, B. Standard Operating Procedure (SOP) for the Analysis of Low Volatile Sulfur Compounds Using Headspace and GC-PFPD; Department of Microbiology Biochemistry Hochschule Geisenheim University: Geisenheim, Germany, 2017.

39. Taillandier, P.; Lai, Q.P.; Julien-Ortiz, A.; Brandam, C. Interactions between Torulaspora delbrueckii and Saccharomyces cerevisiae in wine fermentation: Influence of inoculation and nitrogen content. World J. Microbiol. Biotechnol. 2014, 30, 1959-1967. [CrossRef]

40. Gutiérrez, A.R.; Santamaría, P.; Epifanio, S.; Garijo, P.; López, R. Ecology of spontaneous fermentation in one winery during 5 consecutive years. Lett. Appl. Microbiol. 1999, 29, 411-415. [CrossRef] 
41. Nissen, P.; Neilsen, D.; Arneborg, N. The relative glucose uptake abilities of non-Saccharomyces yeasts play a role in their coexistence with Saccharomyces cerevisiae in mixed cultures. Appl. Microbiol. Biotechnol. 2004, 64, 543-550. [CrossRef]

42. Stratford, M.; Anslow, P.A. Comparison of the inhibitory action on Saccharomyces cerevisiae of weak- acid preservatives, uncouplers, and medium-chain fatty acids. FEMS Microbiol. Lett. 1996, 142, 53-58. [CrossRef] [PubMed]

43. Stanley, G.A.; Douglas, N.G.; Every, E.J.; Tzanatos, T.; Pamment, N.B. Inhibition and stimulation of yeast growth by acetaldehyde. Biotechnol. Lett. 1993, 15, 1199-1204. [CrossRef]

44. Palfree, R.G.E.; Bussey, H. Yeast Killer Toxin: Purification and Characterisation of the Protein Toxin from Saccharomyces cerevisiae. Eur. J. Biochem. 1979, 93, 487-493. [CrossRef] [PubMed]

45. Santos, A.; San Mauro, M.; Bravo, E.; Marquina, D. PMKT2, a new killer toxin from Pichia membranifaciens, and its promising biotechnological properties for control of the spoilage yeast Brettanomyces bruxellensis. Microbiology 2009, 155, 624-634. [CrossRef]

46. Belda, I.; Ruiz, J.; Alonso, A.; Marquina, D.; Santos, A. The biology of Pichia membranifaciens killer toxins. Toxins 2017, 9, 112. [CrossRef] [PubMed]

47. Albergaria, H.; Francisco, D.; Gori, K.; Arneborg, N.; Gírio, F. Saccharomyces cerevisiae CCMI 885 secretes peptides that inhibit the growth of some non-Saccharomyces wine-related strains. Appl. Microbiol. Biotechnol. 2010, 86, 965-972. [CrossRef] [PubMed]

48. Holzberg, I.; Finn, R.K.; Steinkraus, K.H. A kinetic study of the alcoholic fermentation of grape juice. Biotechnol. Bioeng. 1967, 9, 413-427. [CrossRef]

49. Comitini, F.; Gobbi, M.; Domizio, P.; Romani, C.; Lencioni, L.; Mannazzu, I.; Ciani, M. Selected non-Saccharomyces wine yeasts in controlled multistarter fermentations with Saccharomyces cerevisiae. Food Microbiol. 2011, 28, 873-882. [CrossRef]

50. Azzolini, M.; Tosi, E.; Lorenzini, M.; Finato, F.; Zapparoli, G. Contribution to the aroma of white wines by controlled Torulaspora delbrueckii cultures in association with Saccharomyces cerevisiae. World J. Microbiol. Biotechnol. 2015, 31, 277-293. [CrossRef]

51. Sun, S.Y.; Gong, H.S.; Jiang, X.M.; Zhao, Y.P. Selected non-Saccharomyces wine yeasts in controlled multistarter fermentations with Saccharomyces cerevisiae on alcoholic fermentation behaviour and wine aroma of cherry wines. Food Microbiol. 2014, 44, 15-23. [CrossRef] [PubMed]

52. Mallet, S.; Arellano, M.; Boulet, J.C.; Couderc, F. Determination of tartaric acid in solid wine residues by capillary electrophoresis and indirect UV detection. J. Chromatogr. A 1999, 853, 181-184. [CrossRef]

53. Gao, C.; Fleet, G.H. Degradation of malic and tartaric acids by high density cell suspensions of wine yeasts. Food Microbiol. 1995, 12, 65-71. [CrossRef]

54. Seo, S.-H.; Rhee, C.-H.; Park, H.-D. Degradation of malic acid by Issatchenkia orientalis KMBL 5774, an acidophilic yeast strain isolated from Korean grape wine pomace. J. Microbiol. 2007, 45, 521-527. [PubMed]

55. Kim, D.H.; Hong, Y.A.; Park, H.D. Co-fermentation of grape must by Issatchenkia orientalis and Saccharomyces cerevisiae reduces the malic acid content in wine. Biotechnol. Lett. 2008, 30, 1633-1688. [CrossRef] [PubMed]

56. Hong, S.K.; Lee, H.J.; Park, H.J.; Hong, Y.A.; Rhee, I.K.; Lee, W.H.; Choi, S.W.; Lee, O.S.; Park, H.D. Degradation of malic acid in wine by immobilized Issatchenkia orientalis cells with oriental oak charcoal and alginate. Lett. Appl. Microbiol. 2010, 50, 522-529. [CrossRef] [PubMed]

57. Benito, S.; Palomero, F.; Gálvez, L.; Morata, A.; Calderón, F.; Palmero, D.; Suárez-Lepe, J.A. Quality and composition of red wine fermented with Schizosaccharomyces pombe as sole fermentative yeast, and in mixed and sequential fermentations with Saccharomyces cerevisiae. Food Technol. Biotechnol. 2014, 52, 376.

58. Kapsopoulou, K.; Kapaklis, A.; Spyropoulos, H. Growth and fermentation characteristics of a strain of the wine yeast Kluyveromyces thermotolerans isolated in Greece. World J. Microbiol. Biotechnol. 2005, 21, 1599-1602. [CrossRef]

59. Gobbi, M.; Comitini, F.; Domizio, P.; Romani, C.; Lencioni, L.; Mannazzu, I.; Ciani, M. Lachancea thermotolerans and Saccharomyces cerevisiae in simultaneous and sequential co-fermentation: A strategy to enhance acidity and improve the overall quality of wine. Food Microbiol. 2013, 33, 271-281. [CrossRef]

60. Benito, Á.; Calderón, F.; Benito, S. Combined use of S. pombe and L. thermotolerans in winemaking. Beneficial effects determined through the study of wines' analytical characteristics. Molecules 2016, 21, 1744. [CrossRef] [PubMed] 
61. Escribano, R.; González-Arenzana, L.; Portu, J.; Garijo, P.; López-Alfaro, I.; López, R.; Santamaría, P.; Gutiérrez, A.R. Wine aromatic compound production and fermentative behaviour within different non-Saccharomyces species and clones. J. Appl. Microbiol. 2018, 124, 1521-1531. [CrossRef]

62. Escribano-Viana, R.; González-Arenzana, L.; Portu, J.; Garijo, P.; López-Alfaro, I.; López, R.; Santamaría, P.; Gutiérrez, A.R. Wine aroma evolution throughout alcoholic fermentation sequentially inoculated with non-Saccharomyces/Saccharomyces yeasts. Food Res. Int. 2018, 112, 17-24. [CrossRef] [PubMed]

63. Bartowsky, E.J.; Henschke, P.A. Acetic acid bacteria spoilage of bottled red wine-A review. Int. J. Food Microbiol. 2008, 125, 60-70. [CrossRef] [PubMed]

64. Sadoudi, M.; Tourdot-Maréchal, R.; Rousseaux, S.; Steyer, D.; Gallardo-Chacón, J.J.; Ballester, J.; Vichi, S.; Guérin-Schneider, R.; Caixach, J.; Alexandre, H. Yeast-yeast interactions revealed by aromatic profile analysis of Sauvignon Blanc wine fermented by single or co-culture of non-Saccharomyces and Saccharomyces yeasts. Food Microbiol. 2012, 32, 243-253. [CrossRef] [PubMed]

65. Contreras, A.; Hidalgo, C.; Henschke, P.A.; Chambers, P.J.; Curtin, C.; Varela, C. Evaluation of non-Saccharomyces yeasts for the reduction of alcohol content in wine. Appl. Environ. Microbiol. 2014, 80, 1670-1678. [CrossRef] [PubMed]

66. Vilela, A. Lachancea thermotolerans, the Non-Saccharomyces Yeast that Reduces the Volatile Acidity of Wines. Fermentation 2018, 4, 56. [CrossRef]

67. Porter, T.J.; Divol, B.; Setati, M.E. Lachancea yeast species: Origin, biochemical characteristics and oenological significance. Food Res. Int. 2019, 119, 378-389. [CrossRef]

68. Jolly, N.P.; Varela, C.; Pretorius, I.S. Not your ordinary yeast: Non-Saccharomyces yeasts in wine production uncovered. FEMS Yeast Res. 2014, 14, 215-237. [CrossRef]

69. García, M.; Esteve-Zarzoso, B.; Arroyo, T. Non-Saccharomyces Yeasts: Biotechnological Role for Wine Production. In Grape and Wine Biotechnology; InTech: London, UK, 2016.

70. du Plessis, H.; du Toit, M.; Nieuwoudt, H.; van der Rijst, M.; Kidd, M.; Jolly, N. Effect of Saccharomyces, Non-Saccharomyces Yeasts and Malolactic Fermentation Strategies on Fermentation Kinetics and Flavor of Shiraz Wines. Fermentation 2017, 3, 64. [CrossRef]

71. García, M.; Esteve-Zarzoso, B.; Cabellos, J.; Arroyo, T. Advances in the Study of Candida stellata. Fermentation 2018, 4, 74. [CrossRef]

72. Zohre, D.E.; Erten, H. The influence of Kloeckera apiculata and Candida pulcherrima yeasts on wine fermentation. Process Biochem. 2002, 38, 319-324. [CrossRef]

73. Clemente-Jimenez, J.M.; Mingorance-Cazorla, L.; Martínez-Rodríguez, S.; Las Heras-Vázquez, F.J.; Rodríguez-Vico, F. Molecular characterization and oenological properties of wine yeasts isolated during spontaneous fermentation of six varieties of grape must. Food Microbiol. 2004, 21, 149-155. [CrossRef]

74. Varela, C.; Sengler, F.; Solomon, M.; Curtin, C. Volatile flavour profile of reduced alcohol wines fermented with the non-conventional yeast species Metschnikowia pulcherrima and Saccharomyces uvarum. Food Chem. 2016, 29, 57-64. [CrossRef] [PubMed]

75. Belda, I.; Navascués, E.; Marquina, D.; Santos, A.; Calderon, F.; Benito, S. Dynamic analysis of physiological properties of Torulaspora delbrueckii in wine fermentations and its incidence on wine quality. Appl. Microbiol. Biotechnol. 2015, 99, 1911-1922. [CrossRef] [PubMed]

76. Amaya-Delgado, L.; Herrera-López, E.J.; Arrizon, J.; Arellano-Plaza, M.; Gschaedler, A. Performance evaluation of Pichia kluyveri, Kluyveromyces marxianus and Saccharomyces cerevisiae in industrial tequila fermentation. World J. Microbiol. Biotechnol. 2013, 29, 875-881. [CrossRef]

77. Lu, Y.; Huang, D.; Lee, P.R.; Liu, S.Q. Assessment of volatile and non-volatile compounds in durian wines fermented with four commercial non-Saccharomyces yeasts. J. Sci. Food Agric. 2016, 96, 1511-1521. [CrossRef]

78. Fleet, G.H. Yeast interactions and wine flavour. Int. J. Food Microbiol. 2003, 86, 11-22. [CrossRef]

79. Ruiz, J.; Kiene, F.; Belda, I.; Fracassetti, D.; Marquina, D.; Navascués, E.; Calderón, F.; Benito, A.; Rauhut, D.; Benito, S. Effects on varietal aromas during wine making: A review of the impact of varietal aromas on the flavor of wine. Appl. Microbiol. Biotechnol. 2019, 1-26. [CrossRef]

80. Pereira, C.S.M.; Silva, V.M.T.M.; Rodrigues, A.E. Ethyl lactate as a solvent: Properties, applications and production processes-A review. Green Chem. 2011, 13, 2658-2671. [CrossRef]

81. Mestres, M.; Busto, O.; Guasch, J. Analysis of organic sulfur compounds in wine aroma. J. Chromatogr. A 2000, 881, 569-581. [CrossRef] 
82. Jiranek, V.; Langridge, P.; Henschke, P.A. Regulation of hydrogen sulfide liberation in wine-producing Saccharomyces cerevisiae strains by assimilable nitrogen. Appl. Environ. Microbiol. 1995, 61, 461-467.

83. Mendes-Ferreira, A.; Mendes-Faia, A.; Leão, C. Survey of hydrogen sulphide production by wine yeasts. J. Food Prot. 2002, 65, 1033-1037. [CrossRef]

84. Renault, P.; Miot-Sertier, C.; Marullo, P.; Hernández-Orte, P.; Lagarrigue, L.; Lonvaud-Funel, A.; Bely, M. Genetic characterization and phenotypic variability in Torulaspora delbrueckii species: Potential applications in the wine industry. Int. J. Food Microbiol. 2009, 134, 201-210. [CrossRef]

(C) 2019 by the authors. Licensee MDPI, Basel, Switzerland. This article is an open access article distributed under the terms and conditions of the Creative Commons Attribution (CC BY) license (http://creativecommons.org/licenses/by/4.0/). 